\title{
Crisis events and analysis of selected territorial and spatial impacts
}

\author{
J. Betáková ${ }^{1}$, R. Zeman ${ }^{1}$, J. Dvorský ${ }^{2} \&$ T. Pavlenko ${ }^{2}$ \\ ${ }^{1}$ Institute of Technology and Business in České Budejovice, \\ Czech Republic \\ ${ }^{2}$ Faculty of Security Engineering, University of Žilina, Slovakia
}

\begin{abstract}
Crisis events mostly affect the development of a territory where they occur in a negative way. The calculation of the relevant statistical indicators resulting from emerged crisis events is problematic within the countries that make up the Visegrad Group. This is due to the fragmented legislative framework of terms. The perception of natural risks by residents that are associated with the emergence of a crisis event is the basis for subsequent priority setting within the territorial unit. When evaluating the perception of selected natural hazards which occur the most frequently in central Europe, we used the quantitative method of mathematical statistics called the "analysis of variance". This paper goes on to consider the incorporation and implementation of risk management into territorial plans as a preventive measure to increase safety. Risk management contributes significantly to the protection of human life, material and cultural values, as well as the environment. At the same time it increases the level of comprehensive safety in urban areas. As a result, the probability of a crisis event emerging are reduced thereby reducing the costs of eliminating their negative consequences.
\end{abstract}

Keywords: management, plan, prevention, crisis event.

\section{Introduction}

The consequence of social development is an immediate need for a broad territorial development plan which has a synergic effect. Spatial planning forms prerogatives for the harmonisation and functional use of territory. Crisis events which occur in a particular territory have detrimental consequences for territorial 
development. This paper contains statistical data relating to critical phenomena in the territory covered by the Visegrad Group. The analysis of their characteristics and the evaluation of their perception by the population, which is based on an opinion poll, is the source of improved prevention of such phenomena. The objective of the case study is to determine the perception and the level of attention paid to the threat posed by natural hazards. It is based on the perspectives of the inhabitants of the White Carpathian Euroregion. The results have been achieved using the method of the quantitative statistics of analysis of variance. The analyses were based on the identification of the statistical characteristics of the opinion poll with regards to the critical phenomena (average, variance, standard deviation). Comparisons were then drawn between the citizens of the Slovak Republic and the Czech Republic. The comparison of the characteristics was conducted with the use of parametric Ftest, Kruskal-Wallis test, which was possible because of the appropriate conditions for performing the test i.e. variance identity and normal division.

\section{Environmental crisis events in the Slovak Republic and the other V4 (Visegrad Group) countries}

The Visegrad Group is an informal bloc of four Central European countries - the Slovak Republic, Czech Republic, Hungary and Poland. The V4 is a dynamic regional group of EU countries. It creates the conditions for the enhancement of coordination and consulting mechanisms which aim to seek common positions and standpoints on current foreign and European policy, regional development, and economic and cultural cooperation.

Table 1: Characteristics of the crisis events in the V4 countries during the monitored period (1993-2014) [1].

\begin{tabular}{|c|c|c|c|c|c|c|c|}
\hline Country & $\begin{array}{c}\text { Number } \\
\text { of crisis } \\
\text { events }\end{array}$ & Fatalities & $\begin{array}{c}\text { Inhabitants' } \\
\text { interventions }\end{array}$ & $\begin{array}{c}\text { Inhabitants' } \\
\text { injuries }\end{array}$ & Homeless & $\begin{array}{c}\text { Total number } \\
\text { of affected } \\
\text { inhabitants }\end{array}$ & $\begin{array}{c}\text { Damages } \\
(\boldsymbol{€})\end{array}$ \\
\hline $\begin{array}{c}\text { Slovak } \\
\text { Republic }\end{array}$ & 24 & 266 & 57,537 & 418 & 1,697 & 59,652 & $\mathbf{7 8 5 , 6 0 0}$ \\
\hline $\begin{array}{c}\text { Czech } \\
\text { Republic }\end{array}$ & 27 & 634 & $1,607,950$ & 2,563 & 11,973 & $1,622,486$ & $\mathbf{5 , 9 6 4 , 1 1 2}$ \\
\hline Poland & 50 & 2,271 & 285,600 & 736 & 62,000 & 348,336 & $\mathbf{7 , 5 4 7 , 0 5 0}$ \\
\hline Hungary & 35 & 887 & 243,620 & 1,068 & 9,383 & 254,071 & $\mathbf{1 , 1 5 4 , 4 0 0}$ \\
\hline TOTAL & $\mathbf{1 3 6}$ & $\mathbf{4 , 0 5 8}$ & $\mathbf{2 , 1 9 4 , 7 0 7}$ & $\mathbf{4 , 7 8 5}$ & $\mathbf{8 5 , 0 5 3}$ & $\mathbf{2 , 2 8 4 , 5 4 5}$ & $\mathbf{1 5 , 4 5 1 , 1 6 2}$ \\
\hline
\end{tabular}

According to EM-DAT database the total number of the crisis events in the Visegrad Group countries was 136. The highest number of crisis events occurred in Poland and the lowest number occurred in the Slovak Republic (see Figure 1) [1]. 


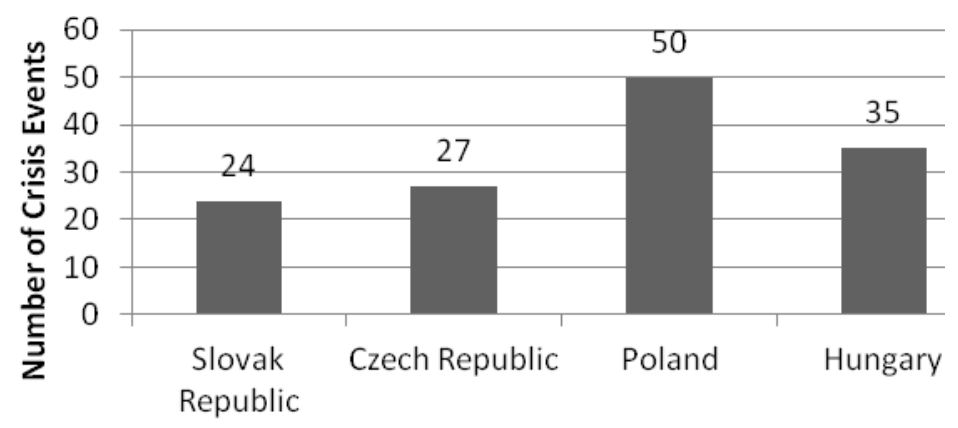

Visegrad Group Countries

Figure 1: Comparison of the number of crisis events in the V4 countries during the monitored period (1993-2014).

The highest number of crisis events in Poland is also related to the highest number of fatalities (in total 2,271) in comparison to other countries. The highest number of affected inhabitants was in the Czech Republic. The number of affected inhabitants is five times higher in the Czech Republic than in comparison to Poland. This is in spite of the fact that the number of crisis events in the Czech Republic was half that in Poland. The reason for this is the influence of specific geographic data e.g. population density. The lowest number of injured inhabitants (418) and of homeless inhabitants $(1,697)$ was in the Slovak Republic. The total amount of damages incurred in the V4 countries was $€ 15,415,162$. The lowest share of the total damages incurred was in the Slovak Republic $-5 \%$ which equates to $€ 785,600$. The second lowest share of total damages incurred was in Hungary $-7 \%$ which equates to $€ 1,154,400$.

Figure 2 proves that the crisis events caused the greatest damages in the Czech Republic and in Poland. The damages incurred in the Czech Republic amounted to $€ 5,964,112$ during the period 1993-2014. Poland has the most significant share of damages $-49 \%$ or $€ 547,050$. The increasing trend in the number of crisis events in a particular territory means that it is appropriate to introduce preventive measures subject to the implementation of a proper concept and the management thereof. In so doing, the subsequent costs for the elimination of effects of the crisis events may be reduced and the security and protection of the population may increase. The crisis events in the Slovak Republic refer to all the events, ongoing actions and events which have threatened the security or existence of particular subjects or which have prevented the materialisation of the planned processes [2]. As mentioned above, crisis events may also be perceived as being extraordinary events, however extraordinary events are well defined. Extraordinary events which influence the life, health or wealth in a negative way are defined in the Law of the National Council of the Slovak Republic No. 42/1994 in the amended Code on the Civil Protection of the Population: 
Natural disasters - are extraordinary events which have occurred as a consequence of the detrimental effect of natural forces. Examples of natural disasters are:

1. Territory possibly threatened by flooding from surface watercourses;

2. Territory threatened by large scale forest fire;

3. Territory possibly threatened by seismic activity, landslide, landslide of rocks or avalanche;

4. Extraordinary event of air or climatic nature.

Accident - is a deviation from normal operations the consequences of which are a leak of a hazardous substance or the working of destructive factors which are detrimental to life, health or wealth. The extraordinary event as the result of a chemical leak and other dangerous substances is an example of an accident.

Disaster - is an increase in destructive factors and their consequent accumulation which comes as a result of natural calamities and accidents. A small part of natural calamities and accidents are called a disaster. Examples of a disaster are larger scale earthquakes, aviation and naval accidents, accidents involving nuclear facilities and the destruction of water works [3].

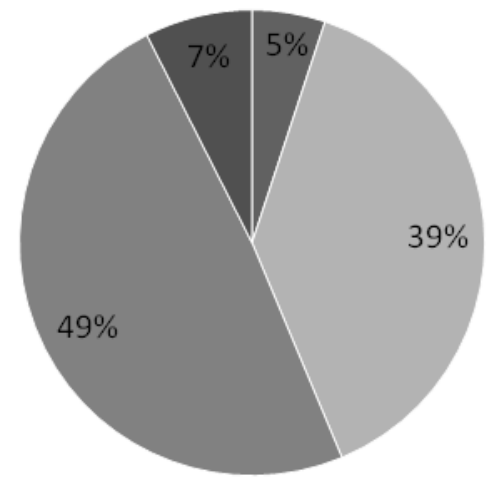

Slovak Republic

Czech Republic

Poland

Hungary

Figure 2: Percentage of the total damages incurred in the V4 countries.

\section{Methodology of research and analysis of variance of the respondents evaluation of crisis events}

The focus of attention of the research was on the perception of the risks of extraordinary events based on the perception of the population of the White Carpathian Euroregion. The objective of the research was to focus attention on an analysis of the facts and the trends in the White Carpathian Euroregion e.g. Biele Karpaty (Slovak Republic - SR) and Bile Karpaty (Czech Republic - CR). The basic framework for the research was formed by the links between the continuity of territorial development and the real use of the territorial potential within the territorial structure. The analysis of the perception of security was a partial objective. Based on the target group's perspective, security was regarded 
as a category under quality of life and the system of values of individual agents of this developing process. The methods of logical research and the comparative method have been employed in this paper. The analytic and synthetic method were utilized to examine the instruments of spatial management. The method of induction and deduction was used to describe the results. The basis of the methodology of the research is the principle of multi-level complex analysis of selected activities and factors which influence the development of residential structures. There were three phases to the research:

- analysis of the theoretical knowledge and practical experience which are compatible with the implementation of the selected instruments of spatial management which have an impact on the development of residential structures;

- analysis, quantification and use of qualitative methods for the evaluation of the synergic and cumulative effects within the context of sustainable development and the system of planning mechanisms;

- summary of the conclusions which are suitable for the practical use of progressive attitudes to evaluate the potential development of residential structures.

The complex research was conducted within the framework of the KEGA No 005 DTI-4-2014 project entitled "Sector Integration of the Spatial Effects of Spatial Management". The research sample was 360 respondents from the Slovak Republic during May-July 2014. Direct data were collected through an on-line survey, standardized writing and questionnaire i.e. exploratory method. The procedure for the on-line survey was as follows:

- final form of the questionnaire was designed in web form and placed on the Internet and social networks;

- after successful completion of the questionnaire the respondents were contacted by e-mail which contained an Internet address and password;

- data collection was halted upon achieving the desired sample quota (the general advantage of on-line research is that it is possible to monitor in real time the current status and level of quotas, as well as generate preliminary statistics);

- collected data were controlled with regard to their consistency, seriousness and logical continuity. Inappropriate responses (dialogues) were eliminated. The statistical features of the respondents were combined with the data for subsequent processing in a statistical programme.

The use of the method of analysis of variables for evaluation purposes made it possible to judge whether the selected crisis events, as perceived by the respondents in the countries of the White Carpathian Euroregion, are comparable. The individual respondents were able to evaluate the selected crisis events on a scale of $1-10$, whereby 1 represented the smallest threat of a crisis event and 10 represented the largest threat of a crisis event. The processing of the analysis of variables is complicated and was therefore conducted with the help of STATGRAPHICS CENTURION XVII. statistical software [4].

The selected crisis events which threaten the security of the respondents in the White Carpathian Euroregion are: 
1. flood,

2. extreme temperature,

3. storm,

4. fire,

5. landslide,

6. windstorm,

7. earthquake.

The following are the steps involved in the analysis of variance [5]:

- to calculate the sample characteristics (mean value, variance) of the evaluation of the selected crisis event in the case study conducted in the selected countries;

- to decide whether it is appropriate to use either a parametric or a nonparametric test in the analysis of variance of the evaluation of the selected crisis event with regards to the conditions which were defined for each test;

- to test the variance of the evaluation of the crisis events with the use of parametric F-test and non-parametric Kruskal-Wallis test;

- to state whether the mean values of the evaluation of the origin of the selected crisis events are comparable between the individual countries.

\section{The analysis of variance of the respondents' evaluation of the origin of the crisis events}

As the required data for the analysis of variance are given in Table 2 . They are the basic sample characteristics (BSC) [6]:

- $\mu-$ mean values of the respondents' evaluation of the origin of the crisis events,

- $\sigma^{2}$ - variance of the respondents' evaluation of the origin of the crisis events.

Table 2: Basic sample characteristics of the respondents' evaluation of the origin of the crisis events

\begin{tabular}{|c|c|c|c|c|}
\hline \multirow{2}{*}{ Crisis events } & \multicolumn{2}{|c|}{ SR } & \multicolumn{2}{c|}{ CR } \\
\cline { 2 - 5 } & $\boldsymbol{\mu}$ & $\sigma^{2}$ & $\boldsymbol{\mu}$ & $\sigma^{2}$ \\
\hline $\mathbf{1}$ & 9.18 & 1.65 & 9.27 & 1.81 \\
\hline $\mathbf{2}$ & 6.49 & 2.84 & 4.71 & 3.64 \\
\hline $\mathbf{3}$ & 3.51 & 4.81 & 2.81 & 2.79 \\
\hline $\mathbf{4}$ & 5.33 & 2.04 & 5.79 & 4.14 \\
\hline $\mathbf{5}$ & 2.93 & 2.11 & 2.25 & 3.77 \\
\hline $\mathbf{6}$ & 4.46 & 2.17 & 3.78 & 1.89 \\
\hline $\mathbf{7}$ & 1.01 & 1.20 & 1.14 & 1.38 \\
\hline
\end{tabular}

The analysis of variance was conducted with the parametric F-test or the nonparametric Kruskal-Wallis test [7, 8]. It was possible to conduct a parametric test provided two essential conditions were met: 
- homoscedasticity - the identity of the variance of the respondent's evaluation of the selected crisis events in the White Carpathian Euroregion. The results are summarized in Table 3;

- normality of groups - the probabilistic model of the normal division of values of the respondent's evaluation of the selected crisis events in the White Carpathian Euroregion. The results are presented in Table 4.

It was possible to conduct the non-parametric Kruskal-Wallis test on the condition that homoscedasticity of the variance was present. However, the evaluation of the crisis events was not regularly divided.

Table 3: Bartlett test for the purpose of the evaluation of the homoscedasticity of the evaluation of the crisis events.

\begin{tabular}{|c|c|}
\hline Crisis events & $\begin{array}{c}\text { Bartlett test } \\
\text { (P-value) }\end{array}$ \\
\hline $\mathbf{1}$ & 0.184 \\
\hline $\mathbf{2}$ & 0.254 \\
\hline $\mathbf{3}$ & 0.507 \\
\hline $\mathbf{4}$ & 0.084 \\
\hline $\mathbf{5}$ & 0.243 \\
\hline $\mathbf{6}$ & 0.186 \\
\hline $\mathbf{7}$ & 0.898 \\
\hline
\end{tabular}

Table 4: Pearson $\chi^{2}$-test for the purpose of the verification of the normality of the evaluation of the crisis events.

\begin{tabular}{|c|c|}
\hline Crisis events & $\begin{array}{c}\text { Pearson } \boldsymbol{\chi}^{\mathbf{2}} \text { test } \\
\text { (P-value) }\end{array}$ \\
\hline $\mathbf{1}$ & 0.002 \\
\hline $\mathbf{2}$ & 0.157 \\
\hline $\mathbf{3}$ & 0.000 \\
\hline $\mathbf{4}$ & 0.204 \\
\hline $\mathbf{5}$ & 0.354 \\
\hline $\mathbf{6}$ & 0.025 \\
\hline $\mathbf{7}$ & 0.543 \\
\hline
\end{tabular}

The results of the Bartlett test prove that there is a 0.95 probability that there are identical variances in the respondents' evaluation of the selected crisis events in the White Carpathian Euroregion. The Pearson $\chi^{2}$-test proves that the respondents assessed the crisis events of extreme heat, fire, landslide and earthquake with a significance level of 0.05 . The presence of the crisis events made it possible to conduct the parametric F-test on the analysis of variance because all the conditions were met. In contrast, the P-value of the Pearson $\chi^{2}$ test for the crisis events of flood, storm and windstorm were lower than the significance level of 0.05 . As a result, it is appropriate to refute the assumption 
that there are regular divisions in the identical variances of evaluation of the origin of the selected crisis events in the White Carpathian Euroregion. In light of this it was possible to conduct the non-parametric Kruskal-Wallis test as the conditions of the crisis events were met. The results of the analysis of variance of the respondents' evaluation of the origin of the crisis events with the use of the parametric and non-parametric test are summarized in Tables 5 and 6.

Table 5: Parametric F-test.

\begin{tabular}{|c|c|}
\hline Crisis events & $\begin{array}{c}\text { F- test } \\
\text { (P-value) }\end{array}$ \\
\hline $\mathbf{2}$ & 0.017 \\
\hline $\mathbf{4}$ & 0.039 \\
\hline $\mathbf{5}$ & 0.027 \\
\hline $\mathbf{7}$ & 0.415 \\
\hline
\end{tabular}

Table 6: Non-parametric Kruskal-Wallis test.

\begin{tabular}{|c|c|}
\hline Crisis events & $\begin{array}{c}\text { Kruskal-Wallis test } \\
\text { (P-value) }\end{array}$ \\
\hline $\mathbf{1}$ & 0.562 \\
\hline $\mathbf{3}$ & 0.006 \\
\hline $\mathbf{6}$ & 0.044 \\
\hline
\end{tabular}

The interpretation of the results of the analysis of variance of the respondent's evaluation of the origin of the crisis events in Tables 5 and 6 follow below. It is assumed that with a 0.95 reliability rate the following crisis events are comparable:

- flood,

- earthquake,

as stated by the respondents from the White Carpathian Euroregion. There are not any statistically significant differences in the evaluation of the crisis events in terms of the statistically representative samples of the survey. There are statistically significant differences with regards to respondents' evaluation of the other crisis events.

\section{Conclusion}

The crisis events in the Visegrad Group of countries cause significant damage. The inclusion of preventive measures into spatial plans is an essential step towards reducing the effects of the crisis events. This paper deals with the members of the Visegrad Group of countries i.e. the Slovak Republic and the Czech Republic. The research focuses on the White Carpathian Euroregion. The results of the mathematical method of the analysis of variance proves that the evaluation of the selected crisis events i.e. extreme temperature, storm, fire, 
landslide or windstorm, is not influenced by nation. The research was conducted with a sample population from the White Carpathian Euroregion. However, the crisis events of flood and earthquake are influenced by nation in terms of their evaluation. The populations of both countries of the White Carpathian Euroregion agreed in the survey, that the most significant natural risk that they feel threatened by is that of flooding. On the contrary, the population of the surveyed territory regarded the natural risk of earthquake as insignificant and rare.

\section{Acknowledgements}

The authors would like to thank the Ministry of Education of the Slovak Republic and the Faculty of Security Engineering, University of Zilina for their support of the grant project KEGA Project 005 DTI-4/2014.

\section{References}

[1] EM-DAT Database Advanced Search, 2015, (online). (cit. 2015-1-15]). Available at: http://www.emdat.be/advanced_search/index.html

[2] Šimák, L.: Krízový manažment vo verejnej správe. FŠI ŽU v Žiline, 2004, ISBN 80-88829-13-5.

[3] Zákon č. 42/1994 Z. z. Národnej rady Slovenskej republiky z 27. januára 1994 o civilnej ochrane.

[4] Statgraphics: Software Statgraphics Centurion XVII. 2015, (online). (cit. 2015-1-18). Available at: http://info.statgraphics.com/download-trial?\& hssc $=\&$ hstc \&hsCtaTracking $=d 8 \mathrm{e} 0219 \mathrm{~d}-8368-487 \mathrm{~d}-\mathrm{a} 39 \mathrm{~b}-8 \mathrm{f} 69849 \mathrm{e} 1$ 868|ca001 1b4-305c-43fe-b137-ea927ae0ac37

[5] Lámoš, F., Potocký, R.: Pravdepodobnost' a matematická štatistika, Bratislava: Vydavatelstvo UK, pp. 125-127, 1998.

[6] Betaková, J., Haviernikova, K., Dvorský, J.: The issues of clusters potential assessing in the regions of Slovak Republic. 2nd International Conference on Management Innovation and Business Innovation, Bangkok, 2014, ISBN 978-981-09-1685-5, pp. 122-127, 2014.

[7] Sipková, L'., Sodomová, E.: Modelovanie kvantilovými funkciami, Bratislava: Ekonom, p. 175, 2007.

[8] Betáková, J., Lorko, M., Dvorský J.: The impact of the potential risks of the implementation of instruments for environmental area management on the development of urban settlement, Environmental impact II, Ancona, 2014, ISBN 978-184564762-9, ISSN 17433541, pp. 91-101. 